\title{
Transparency of the Concepts of Directing and Leadership in Organizational Leadership Theory based on Critical Hermeneutics Theory
}

\author{
Shalaleh Kameli ${ }^{1}$, Shahram Mirzaei Daryani ${ }^{2 *}$, Mohammad Kheirandish ${ }^{3}$, Majid \\ Ahmadlou ${ }^{4}$
}

1, 2,3, ${ }^{2}$ Department of Management, Ardabil Branch, Islamic Azad University, Ardabil, Iran

Keywords:

Leadership, Directing,

Critical hermeneutics theory

\section{Received}

04 August 2020

Received in revised form

28 August 2020

Accepted

07 September 2020

\begin{abstract}
Some researchers consider leadership and directing to be equivalent as much as they use them interchangeably. According to the study of the historical course done in this research, this issue has been seen more than ever in recent texts. In this study, the critical hermeneutics of Prasad's (2005) four-stage model was used. In the first stage, the data was collected from books, and papers related to organizational leadership theory. To this end, 61 definitions of organizational leadership and eight definitions of directing have been collected from the viewpoint of management experts. Ambiguities were raised in the form of questions about the intentions of the authors of the relevant texts. In the second stage, layers of texts were interpreted, and themes and concepts were extracted. In the third stage, to close the hermeneutic cycle, a narrative case was used, which is the personal experience of an organizational leader of the distinction between leadership and directing. The final stage was suggested to the researchers not to consider the words 'leadership' and 'directing' equivalent or interchangeable. Directing is a part of leadership that is more or less applied depending on the type of leadership style. It is also recommended for experts in marketing, business and economics to use the alternative terms market pioneer and industry director instead of the words market leader and industry leader because obedience to other organizations may be due to duty not influence or follow-up.
\end{abstract}

*Correspondence:

In some sciences, interpretation is a commonly supported practice. In sciences, such as mathematics and physics, global signs and standards have fixed concepts, while in humanities, especially when there are cultural and social differences, words depend on human perceptions. In these scopes of 
science, when words are equated with one another and translated into different languages, the translator and their scientific and technical knowledge or even their specialty and study field will play a significant role in equating the words and making their meanings similar. In the present study, we attempted to investigate the meanings of the words 'directing' and 'leadership' in English and Persian literature as well as their similarities and differences. Despite the rich background of this topic, organizational leadership is still one of the most misunderstood business phenomena. Leadership as a concept is highly ambiguous; this ambiguity stems not come from a lack of definitions but rather from an excess of definitions and popular conception. According to Hibbert et al. (2017), leadership definitions are still an actor-based and more referred to as a leader theory rather than leadership theories. Some experts such as Rost (1993) and Bass (1990) believe in the diversity of the definitions of leadership, while other experts such as Fiedler (1978) and Horner (1997) believe in the diversity of leadership theories. Blom and Alvesson (2015) refer to this ambiguity as a hegemonic quality that is broad in an organization. However, the definition of leadership and leadership theory are the same since any expert attempting to define leadership has aimed to develop a framework for understanding leadership. Thus, we face diversity and there is no consensus about how to understand leadership (Bogenschneider, 2016). What requires more transparency in this complication understands the nature of organizational leadership, resolving ambiguities and contradictions. One of the ambiguities in defining organizational leadership is to use similar terms, such as directing. The reason why different experts have used these words as an equivalent for leadership requires investigation. The present study aims to answer the following questions using a critical hermeneutic method: Is leadership in an organization the same as directing? Are these two words interchangeable, especially in the specialized texts of management, and can they be used for exactly a single purpose? If they are different, what are their differences? What necessitates such research is that recently in the management literature, the ambiguity between leadership and leadership is more than ever, which we have revealed by studying the historical course of definitions based on the method of hermeneutic research. In this research, we have attempted to indicate how texts suffer from contradiction and incoherence or weak coherence, so that soon, experts will avoid these ambiguities and organize the topics of organizational leadership.

\section{Background}

Researchers around the English-speaking world have conceptualized leadership as a substance of individual attributes, as particular behavior, as a power relation, as a process, and as combinations of these variables (Caroselli, 2000; Gini \& Green, 2013; Humphrey, 2002; Yammarino, 2013). By reviewing the definitions of leadership, we will find a few points that are valuable emphasizing. First, the lack of a consensus is partly a language problem; second, leadership theories carry unrelated connotations that create ambiguity; this is because terms such as authority and management are used to illustrate similar social phenomena (Bratton, 2020). Another term that is an example of this ambiguity is the term directing. Some experts in the field of organization and management have distinguished between directing and leadership in the literature and resources. In contrast, some other experts do not differentiate between these words and sometimes use them interchangeably. As Bratton (2020) points out, the language problem also has added to this ambiguity. For example, Alvani (2009), known as the father of Iranian public administration science in his book under the title of "General management," has used the terms "directing" and 
"organizational leadership" together. It seems that in terms of application, these words are different and cannot be substituted. In Merriam-Webster, directing in the field of management has been defined as guiding or monitoring the act and behavior (Merriam-Webster's Online Dictionary, 2020), and in Longman and Cambridge, it has been defined as a path someone or something is moving in in order to face or achieve something (Cambridge Online Dictionary, 2020; Longman Online Dictionary, 2020). Leading or being a leader means to be in charge of other people and direct them forward, perhaps because they are not necessarily willing to move. Furthermore, in terms of terminology, leadership is different from the leader (Ladkin, 2020). Leadership is the process of a leader's influence on followers. The way leadership is determined strongly influenced by an individual's philosophical and theoretical point of view. For example, through a psychological point of view, leadership is seen as the consequence of a set of individual characteristics of a leader. In contrast, from a sociological point of view, leadership is a social process based on the relationship between leaders and followers (Bratton, 2020). Definitions based on psychological perspectives are leader-centric definitions and pay less attention to the process nature of leadership and ignore the role of followers.

Ladkin (2020) defines leadership through directing. For him, Leadership requires motivating employees to participate in achieving collective goals by directing them ahead of Maslow's hierarchy. According to Ladkin (2020), leadership and directing are the same and among the functions of managers. He considered leadership as an inevitable part of the role of all managers.

Experts have defined leadership as behavior, method, skill, process, responsibility, experience, one of the managers' duties and roles, influence, or ability. Table 1 includes definitions that are highly referenced in books and articles, the most famous definitions of organizational leadership were collected from the end of the twentieth century to the present, which have been expressed separately by experts and researchers in the field of management in English and Persian language books and articles.

Table 1

A List of Definitions of Leadership in an Organization

\begin{tabular}{|c|c|c|c|}
\hline & Experts & Definition & Concept \\
\hline 1 & (Hersey \& Blanchard, 1969) & Achieving goals, with the help of other people. & Process \\
\hline 2 & $\begin{array}{l}\text { (Kochan, Schmidt, \& } \\
\text { DeCotiis, 1975) }\end{array}$ & $\begin{array}{c}\text { The process of influence whereby a person's action changes the } \\
\text { behavior and opinion of other people. This influence must be legitimate } \\
\text { and cause changes in line with goals. }\end{array}$ & The process of influence \\
\hline 3 & (Burns, 1978) & $\begin{array}{l}\text { - Perhaps it is the most quoted definition of leadership which believes } \\
\text { that leadership occurs when individuals are involved with other } \\
\text { people in a task, so that leaders and followers improve the } \\
\text { motivation and behavior of one another. } \\
\text { - Encouraging or forcing somebody to do a task, to achieve particular } \\
\text { goals which reflect values, motivations, desires, needs, and } \\
\text { expectations. }\end{array}$ & Encouraging or forcing \\
\hline 4 & (Katz \& Kahn, 1978) & $\begin{array}{l}\text { A situational characteristic, personal trait, and behavioral adjective. } \\
\text { Leadership refers to the concept of associating an influencing factor } \\
\text { with people who are influenced. This concept is highly variable and } \\
\text { heavily dependent on situational characteristics and people who must be } \\
\text { directed. }\end{array}$ & $\begin{array}{l}\text { Directing the influenced } \\
\text { people through an } \\
\text { influencing factor }\end{array}$ \\
\hline 5 & (Smircich \& Morgan, 1982) & $\begin{array}{l}\text { Leadership occurs in an environment, and the observer's observations } \\
\text { change an actor into a leader. }\end{array}$ & $\begin{array}{l}\text { Observations and } \\
\text { conceptions }\end{array}$ \\
\hline 6 & (Bennis \& Nanus, 1985) & $\begin{array}{l}\text { The potential of influencing and giving the members of an organization } \\
\text { a sense of meaning. }\end{array}$ & $\begin{array}{l}\text { The potential of } \\
\text { influencing }\end{array}$ \\
\hline 7 & (Yukl, 1989) & $\begin{array}{l}\text { - Influencing goals and work strategies, influencing commitment and } \\
\text { observing work ethic to achieve goals, influencing the identification } \\
\text { and maintenance of the group, and influencing the organizational } \\
\text { culture }\end{array}$ & $\begin{array}{l}\text { The process of } \\
\text { influencing }\end{array}$ \\
\hline
\end{tabular}




\begin{tabular}{|c|c|c|c|}
\hline & & $\begin{array}{l}\text { - The process of influencing other people to reach an agreement on } \\
\text { when and how to do a task. } \\
\text { - A process that facilitates personal and collective attempts to achieve } \\
\text { common goals. }\end{array}$ & \\
\hline 8 & (Gardner, 1990) & $\begin{array}{l}\text { The process of encouraging and persuading people by a person or a } \\
\text { leadership team and forcing them to pursue the goals. }\end{array}$ & $\begin{array}{l}\text { The process of } \\
\text { encouraging and } \\
\text { persuading }\end{array}$ \\
\hline 9 & (Kreitner \& Kinicki, 1992) & $\begin{array}{l}\text { A person who supplements their authority with personal traits and social } \\
\text { skills in order to encourage the employees' voluntary participation. A } \\
\text { process of social influence whereby the leader looks for the voluntary } \\
\text { participation of subordinates to achieve organizational goals. }\end{array}$ & $\begin{array}{l}\text { The process of social } \\
\text { influence and } \\
\text { encouragement }\end{array}$ \\
\hline 10 & (Drath \& Palus, 1994) & $\begin{array}{l}\text { The process of perceiving what people do together in order to provide } \\
\text { understanding and commitment to that task. }\end{array}$ & The process of perception \\
\hline 11 & (Barnard, 1997) & $\begin{array}{l}\text { The behavior quality of individuals who direct other people and their } \\
\text { activities in an organized way. }\end{array}$ & Directing \\
\hline 12 & (Zand, 1997) & $\begin{array}{l}\text { - The process of influencing the activity of an individual or a group to } \\
\text { set and achieve goals } \\
\text { - The ability to influence people through knowledge, trust-building, } \\
\text { and decision-making power. }\end{array}$ & $\begin{array}{l}\text { The process of influence } \\
\text { The ability to influence }\end{array}$ \\
\hline 13 & (Robbins, 1998) & $\begin{array}{l}\text { The ability to influence the group and direct it towards the desired } \\
\text { goals. }\end{array}$ & The ability to influence \\
\hline 14 & (Drucker, 1999) & Any person who has followers is a leader. & Having followers \\
\hline 15 & (Caroselli, 2000) & Using power to make positive changes. & Using power \\
\hline 16 & (Lussier \& Achua, 2001) & $\begin{array}{l}\text { The process of influencing followers depends on an alteration in order } \\
\text { to achieve organizational goals. }\end{array}$ & $\begin{array}{c}\text { The process of } \\
\text { influencing }\end{array}$ \\
\hline 17 & (Humphrey, 2002) & $\begin{array}{l}\text { An emotional process whereby the leader understands, manages, and } \\
\text { provokes their followers' feelings. }\end{array}$ & An emotional process \\
\hline 18 & $\begin{array}{l}\text { (Blanchard \& Muchnick, } \\
\text { 2003) }\end{array}$ & Directing people to a place where they are expected to go. & Directing \\
\hline 19 & $\begin{array}{l}\text { (Alvesson \& Sveningsson, } \\
\text { 2003) }\end{array}$ & A valuable and valid structure for whatever managers do. & $\begin{array}{l}\text { All the structured acts of } \\
\text { managers }\end{array}$ \\
\hline 20 & $\begin{array}{l}\text { (Reiter-Palmon \& Illies, } \\
\text { 2004) }\end{array}$ & Leadership is a creative problem-solving. & Creative problem-solving \\
\hline 21 & (Ciulla, 2005) & $\begin{array}{l}\text { As an act, it refers to the process of directing. Leadership is a particular } \\
\text { type of moral relationships. Leaders can empower people, provided that } \\
\text { they have honest, moral courage. }\end{array}$ & The process of directing \\
\hline 22 & $\begin{array}{l}\text { (Klein, Ziegert, Knight \& } \\
\text { Xiao, 2006) }\end{array}$ & $\begin{array}{l}\text { The concept of leadership is regarded as a delegation whereby the } \\
\text { members of a group give a person authority for a fixed period and under } \\
\text { particular circumstances. }\end{array}$ & Authority \\
\hline 23 & $\begin{array}{l}\text { (Denhardt \& Denhardt, } \\
\text { 2006) }\end{array}$ & $\begin{array}{l}\text { - Leadership is an art. } \\
\text { - Directing as a distinctive human activity. }\end{array}$ & Art \\
\hline 24 & $\begin{array}{l}\text { Posner \& Kouzes }(1988, \text { as } \\
\text { cited in Abu-Tineh, } \\
\text { Khasawneh \& Al-Omari, } \\
\text { 2008) }\end{array}$ & $\begin{array}{l}\text { - Leadership means honesty and transparency, competency, } \\
\text { perspective, inspiration, and creating enthusiasm. }\end{array}$ & $\begin{array}{l}\text { Influence through } \\
\text { personal and behavioral } \\
\text { characteristics }\end{array}$ \\
\hline 25 & (Harris, 2009) & $\begin{array}{l}\text { If power can potentially be given to all the members of an organization, } \\
\text { each member can be regarded as a leader in particular circumstances. }\end{array}$ & Power \\
\hline 26 & (Northouse, 2010) & $\begin{array}{l}\text { A process whereby a person influences a group of people to achieve a } \\
\text { common goal. }\end{array}$ & The process of influence \\
\hline 27 & $\begin{array}{l}\text { (Sugerman \& Scullard, } \\
\text { 2011) }\end{array}$ & $\begin{array}{l}\text { The process of influencing through internal and external cognition of } \\
\text { yourself and other people. }\end{array}$ & $\begin{array}{c}\text { The process of } \\
\text { influencing }\end{array}$ \\
\hline 28 & $\begin{array}{c}\text { (Alvesson \& Spicer, } 2012 \& \\
\text { 2013) }\end{array}$ & $\begin{array}{l}\text { - Exercising predetermined and relatively regular influence and } \\
\text { developing unequal power-based relationships between the leader } \\
\text { and followers } \\
\text { - Beneficial disequilibrium is based on communications in working } \\
\text { relationships that are applied when coordination, rules of } \\
\text { bureaucracy, professionalism, and other control tools do not work } \\
\text { well. } \\
\text { - Leadership is a strong component in defining the meaning of } \\
\text { management, and it is of fundamental importance in developing } \\
\text { ideas, values, conceptions, and feelings }\end{array}$ & $\begin{array}{l}\text { Exercising influence } \\
\text { A component of } \\
\text { management }\end{array}$ \\
\hline 29 & (Gini \& Green, 2013) & $\begin{array}{l}\text { A powerful relationship based on value and morality between leaders } \\
\text { and followers who have a common view and make real changes that } \\
\text { reflect their common goals. }\end{array}$ & Powerful relationship \\
\hline
\end{tabular}




\begin{tabular}{|c|c|c|c|}
\hline 30 & (Yammarino, 2013) & $\begin{array}{l}\text { The process of a multilevel (person with person, group, and } \\
\text { organization) leader-follower interaction occurs in a particular situation, } \\
\text { and the leader and followers set a common goal and attempt to achieve } \\
\text { it together and eagerly. }\end{array}$ & $\begin{array}{l}\text { The process of a } \\
\text { multilevel interaction }\end{array}$ \\
\hline 31 & (Maxwell, 2013) & It is a process, not a situation. It is the same as influence. & The process of influence \\
\hline 32 & (Algahtani, 2014) & $\begin{array}{l}\text { Leadership concentrates on influencing a group of people to achieve a } \\
\text { common goal as well as developing a perspective. }\end{array}$ & $\begin{array}{c}\text { Influencing and } \\
\text { developing a perspective }\end{array}$ \\
\hline 33 & (Collinson \& Tourish, 2015) & $\begin{array}{l}\text { Leadership is associated with exercising power, whether efficient or } \\
\text { inefficient, productive or destructive, stimulative, or repressive. }\end{array}$ & Exercising power \\
\hline 34 & $\begin{array}{l}\text { (Von Rueden \& Van Vugt, } \\
\text { 2015) }\end{array}$ & $\begin{array}{l}\text { Leadership is a fundamental mechanism to solve the problems of } \\
\text { coordination and motivation in organizations and groups. }\end{array}$ & $\begin{array}{l}\text { The mechanism of } \\
\text { solving a problem }\end{array}$ \\
\hline 35 & (Bogenschneider, 2016) & $\begin{array}{l}\text { Leaders cause followers to develop the project with the help of the } \\
\text { determining effect despite the difficulties. }\end{array}$ & Influencing \\
\hline 36 & (Fontana \& Musa, 2017) & $\begin{array}{c}\text { The ability to encourage teams to get involved in collective creativity in } \\
\text { order to obtain the best result. }\end{array}$ & The ability to encourage \\
\hline 37 & $\begin{array}{l}\text { (Griffith, Gibson, Medeiros, } \\
\text { MacDougall, Hardy \& } \\
\text { Mumford, 2018) }\end{array}$ & $\begin{array}{l}\text { Leadership includes two components of leader and follower, who work } \\
\text { together to achieve common goals. Leaders are assigned or emerge in } \\
\text { order to apply the influence strategies formally or informally to } \\
\text { facilitate the process of encouraging followers to achieve common } \\
\text { goals. }\end{array}$ & Influence \\
\hline 38 & (Antonakis \& Day, 2018) & $\begin{array}{l}\text { Formal or informal contextually rooted and goal influencing process } \\
\text { that occurs between a leader and follower, groups of followers, or } \\
\text { institutions }\end{array}$ & influencing \\
\hline 39 & (Alvesson \& Einola, 2019) & $\begin{array}{l}\text { Purposeful and regular influence of subordinates in order to achieve } \\
\text { specific work-related goals with relational nature. }\end{array}$ & Influencing \\
\hline 40 & (Kiliç \& Günsel, 2019) & $\begin{array}{l}\text { Influencing and directing the behavior of employees of the organization } \\
\text { in line with goals. }\end{array}$ & $\begin{array}{l}\text { Influencing } \\
\text { Directing }\end{array}$ \\
\hline 41 & (Bratton, 2020) & $\begin{array}{l}\text { a process of influencing within an employment relationship involving } \\
\text { ongoing human interaction with others wherein those others consent to } \\
\text { achieve a goal }\end{array}$ & Influencing \\
\hline 42 & (Ladkin, 2020) & $\begin{array}{l}\text { a leader helps in the achievement of collective objectives by directing } \\
\text { the focus of a group of individuals towards these objectives and } \\
\text { motivating them for their achievement. }\end{array}$ & directing \\
\hline 43 & (Saatchi, 1996) & $\begin{array}{l}\text { The process of influence over subordinates which motivates them to } \\
\text { attempt voluntarily and willingly to achieve the goals of the } \\
\text { organization. }\end{array}$ & The process of influence \\
\hline 44 & (Afjei, 2006) & The process of influencing followers and being influenced by them. & $\begin{array}{l}\text { The process of } \\
\text { influencing and being } \\
\text { influenced }\end{array}$ \\
\hline 45 & $\begin{array}{c}\text { (Mousakhani \& } \\
\text { Mohammadnia, 2006) }\end{array}$ & $\begin{array}{l}\text { The process of leadership is a function of these variables: leader, } \\
\text { follower, and situation. } \\
\qquad \mathrm{L}=\mathrm{f}(\mathrm{L}, \mathrm{f}, \mathrm{s})\end{array}$ & $\begin{array}{l}\text { A function of leader, } \\
\text { follower, situation }\end{array}$ \\
\hline 46 & $\begin{array}{l}\text { (Salimi \& Shahmandi, } \\
\text { 2008) }\end{array}$ & $\begin{array}{l}\text { The art or process of influencing people so that they attempt willingly } \\
\text { and do their best to achieve the collective goal. }\end{array}$ & $\begin{array}{l}\text { The art or process of } \\
\text { influencing }\end{array}$ \\
\hline 47 & (Alvani, 2009) & $\begin{array}{l}\text { A process whereby the management tries to fulfill other duties in line } \\
\text { with achieving organizational goals and encourage employees to do } \\
\text { their duties willingly through increasing motivation and developing an } \\
\text { effective relationship. }\end{array}$ & Process \\
\hline 48 & $\begin{array}{c}\text { (Janmashayekh \& Barzideh, } \\
\text { 2010) }\end{array}$ & $\begin{array}{l}\text { The process of exercising influence with no force to direct and } \\
\text { coordinate the activities of group members in line with achieving the } \\
\text { goal. }\end{array}$ & $\begin{array}{l}\text { The process of influence } \\
\text { with no force }\end{array}$ \\
\hline 49 & (Farazja \& Khademi, 2011) & $\begin{array}{l}\text { A fundamental process in any organization that is associated with its } \\
\text { success or failure. }\end{array}$ & Process \\
\hline 50 & (Torkzadeh \& Jafari, 2012) & $\begin{array}{l}\text { Leading the organization refers to the ability to switch from the present } \\
\text { situation to the future one through substituting a proportional world } \\
\text { view, so that the thoughts and values created by the new world view can } \\
\text { be changed. Leaders prepare the employees and members for } \\
\text { undergoing new changes to achieve the fundamental goals of the } \\
\text { organization. Thus, revolutions will be initiated in the organization, it } \\
\text { will develop, and its performance will enhance. }\end{array}$ & $\begin{array}{l}\text { The ability to make } \\
\text { changes and accept a new } \\
\text { world view }\end{array}$ \\
\hline
\end{tabular}




\begin{tabular}{|c|c|c|c|}
\hline 51 & $\begin{array}{c}\text { (Hosseini, mousavi \& } \\
\text { Khosravi Laghab, 2014) }\end{array}$ & $\begin{array}{l}\text { Person's ability or potential for leading, guiding, and managing as well } \\
\text { as directing other people's acts and opinions. }\end{array}$ & $\begin{array}{l}\text { The ability to direct the } \\
\text { acts and thoughts }\end{array}$ \\
\hline 52 & (Afjei \& Hamzepour, 2014) & $\begin{array}{l}\text { Leadership as a process means that personality traits do not cause a } \\
\text { leader to influence their followers, however, rather accidental } \\
\text { negotiations and interactions between the leader and followers influence } \\
\text { and change the followers. }\end{array}$ & $\begin{array}{l}\text { The process of } \\
\text { influencing based on } \\
\text { negotiation and } \\
\text { interaction }\end{array}$ \\
\hline 53 & (Rezaian, 2003 \& 2014) & $\begin{array}{l}\text { - A process whereby a person influences a group of people to achieve } \\
\text { a common goal. } \\
\text { - Management is regarded as a particular type of leadership; whereby } \\
\text { organizational goals are the top priority. Leadership is the process of } \\
\text { influence. }\end{array}$ & $\begin{array}{l}\text { The process of } \\
\text { influencing }\end{array}$ \\
\hline 54 & (Zareie Matin, 2014) & A group of skills that almost all of them can be acquired and developed. & Skill \\
\hline 55 & $\begin{array}{l}\text { (Irani, Alvani, Jandaqi \& } \\
\text { Zareie Matin, 2015) }\end{array}$ & $\begin{array}{l}\text { An influencing relationship between the leader and followers who } \\
\text { attempt to make tangible changes and reflect common goals. }\end{array}$ & Influencing \\
\hline 56 & $\begin{array}{c}\text { (Akbari, Kashani \& } \\
\text { Hooshmand Chaijani, 2015) }\end{array}$ & $\begin{array}{l}\text { The process of directing and influencing the activities of the members } \\
\text { of a group or an organization. }\end{array}$ & $\begin{array}{l}\text { The process of directing } \\
\text { and influencing }\end{array}$ \\
\hline 57 & $\begin{array}{l}\text { (Hakkak, Shariatnejad \& } \\
\text { Saedi, 2016) }\end{array}$ & $\begin{array}{l}\text { With the help of personality traits, charisma, strong influence, and a } \\
\text { wider perspective, leaders give subordinates commitment and } \\
\text { enthusiasm, so that they can develop innovative and entrepreneurial } \\
\text { behavior through inspiration. }\end{array}$ & Influence \\
\hline 58 & $\begin{array}{l}\text { (Pourvali, Nouri \& } \\
\text { Hosseini, 2017) }\end{array}$ & Directing is the process of changing and the scene of playing a role. & $\begin{array}{l}\text { Directing and playing a } \\
\text { role }\end{array}$ \\
\hline 59 & (Abolalaie, 2017) & $\begin{array}{c}\text { Leadership is mainly regarded as an art, side by side with the manager } \\
\text { with a long-term perspective, who cares about doing the right things } \\
\text { rather than doing things right. }\end{array}$ & Art \\
\hline 60 & $\begin{array}{l}\text { (Aybaghi Esfahani, Hasani, } \\
\quad \& \text { Ameri, 2018) }\end{array}$ & The ability to reach high organizational levels. & Ability \\
\hline 61 & $\begin{array}{l}\text { (Mirzaei Daryani, } \\
\text { Aslizadeh, \& Sattari } \\
\text { Ardabili, 2019) }\end{array}$ & A process which occurs through influence and follower(s) emerge. & $\begin{array}{l}\text { The process of } \\
\text { influencing }\end{array}$ \\
\hline
\end{tabular}

The most quoted definition of leadership may belong to Burns (1978), who believes that leadership occurs when people are involved with others in a task so that leaders and followers can improve the motivation and behavior of one another.

Among the definitions included in Table 1, Blanchard and Muchnick (2003), Ciulla (2005), Kiliç and Günsel (2019), Hosseini et al. (2014), Akbari et al. (2015), ladkin (2020), and Pourvali et al. (2017) have defined leadership as directing.

In addition to the definitions mentioned above, surprisingly enough, some researchers such as Canton (2013) and Majed (2019) still insist that leadership is the same as directing properly to influence the thoughts, behavior, and actions of people and give them commitment and motivation to achieve specific goals. Nevertheless, these researchers do not differentiate between leadership and directing and use them interchangeably. In the following, some definitions of "directing" provided by the experts of management are included in Table 2. These definitions include the most well-known definitions of directing, which are derived from management books and articles that discussed about directing. The Gulick (1937) definition is almost the most referenced. 
Table 2

A List of Definitions of Directing from the Viewpoint of Management Experts

\begin{tabular}{|c|c|c|c|}
\hline & Experts & Definition & Concept \\
\hline 1 & (Gulick, 1937) & $\begin{array}{l}\text { The duties of managers with the acronym of POSDCORB, i.e., } \\
\text { planning, organizing, staffing, directing, coordinating, reporting, and } \\
\text { budgeting. }\end{array}$ & $\begin{array}{l}\text { One of the duties of } \\
\text { managers }\end{array}$ \\
\hline 2 & (Mackenzie, 1969) & $\begin{array}{l}\text { The duties of managers include planning, organizing, staffing, directing, } \\
\text { and controlling. Directing refers to actions moving people towards the } \\
\text { desired goal. Actions such as the delegation of authority, responsibility } \\
\text { assignment, providing motivation, coordination, settling disputes } \\
\text { between employees, and encouraging creativity and innovation. }\end{array}$ & $\begin{array}{l}\text { One of the duties of } \\
\text { managers }\end{array}$ \\
\hline 3 & (Dimock, 1975) & Determining and issuing job instructions and assigning an active leader. & Issuing instructions \\
\hline 4 & $\begin{array}{l}\text { (Koontz \& O’Donnell, } \\
1976)\end{array}$ & $\begin{array}{l}\text { The duties of managers include planning, organizing, staffing, directing } \\
\text { and leading, and controlling. These duties are related. }\end{array}$ & $\begin{array}{l}\text { One of the duties of } \\
\text { managers }\end{array}$ \\
\hline 5 & (Dale, 1978) & $\begin{array}{l}\text { Directing tells people what to do and watches that they do their best. It } \\
\text { monitors the fulfillment of duties according to the related procedures so } \\
\text { that mistakes are corrected in job instructions. }\end{array}$ & $\begin{array}{l}\text { Issuing job instruction } \\
\text { and monitoring it }\end{array}$ \\
\hline 6 & (Chandra Bose, 2012) & $\begin{array}{l}\text { Directing concentrates on stimulating the members of an organization } \\
\text { to achieve its goals. As quoted by George Terry, directing includes } \\
\text { issuing an instruction, communicating with subordinates, guiding, } \\
\text { motivating, and monitoring them. }\end{array}$ & $\begin{array}{l}\text { Issuing instruction and } \\
\text { motivating }\end{array}$ \\
\hline 7 & (Rudani, 2013) & $\begin{array}{l}\text { Directing is the process of issuing an instruction for guiding and } \\
\text { inspiring people and watching that they do the things right. Important } \\
\text { tools for directing include leadership, motivation, relationship, and } \\
\text { monitoring. }\end{array}$ & $\begin{array}{l}\text { Issuing instruction and } \\
\text { leadership, the tools for } \\
\text { directing }\end{array}$ \\
\hline 8 & (Shinde, 2018) & $\begin{array}{l}\text { When managers direct their subordinates, in fact, they coordinate their } \\
\text { activities and provide them with job instructions and guidance. } \\
\text { Therefore, directing will also provide employees with coordination. }\end{array}$ & $\begin{array}{l}\text { Issuing instruction and } \\
\text { guidance }\end{array}$ \\
\hline
\end{tabular}

The word "directing" means guiding and moving ahead of other people to show the direction. Leaders attempt to help companies achieve their goals at maximum power. Leaders do not stand aside, but rather encourage people and stand in the front to facilitate the progress (Kristiano, Rivai $\&$ Suharto, 2018). Therefore, there is an apparent conflict between the authors over the definitions of leadership and directing. According to these researchers, leaders are directly involved in achieving the goals of organizations. They do not stand aside, while directing and guiding refers to moving ahead of other people to show the direction.

\section{The Study}

The main aim of this study is to reveal the ambiguities in applying the concepts of leadership and directing in organizational leadership theory with the critical hermeneutic approach. Also, the specific objective of this study is to determine the transparency of the meanings of directing and leadership as well as detecting the similarities and differences.

\section{Method}

Critical hermeneutics leads us to meaning in the world as a connected, lived, and practical exercise. It is important to take a critical stance when interpreting. Critical hermeneutics is grounded in historical discourses, and any interpretation of any text must also pay attention to its historical context. Critical hermeneutics is suspicious of any interpretive model that claims to reveal the final truth or the final essence of any text. Critical hermeneutics provides a methodology for arousing critical sensitivity and consciousness through the analysis of the generative themes (Jacobs, 2014). Interpretive research methods, especially the critical hermeneutic method, can be applied to various scientific fields such as organization and management. Applying this research method is significant since, on the one hand, an organization is a social institution and consists of people with various 
values, attitudes, and viewpoints on the organization and its related factors; on the other hand, humanities methods are not based on discovering the existing rules within the organizations but rather on understanding the intentions, goals, and viewpoints of people on particular issues. Therefore, from a critical hermeneutic perspective, neither approach is superior; each is a moment in the interpretive process (Ricoeur, 1978; Thompson, 1981). Having completed the socialhistorical and formal analysis, a researcher must creatively synthesize two moments-in the moment of interpretation-reinterpretation-to produce hermeneutics of the text and its role in the social system of which it is a part such as organization. This analysis of the process provides a structured framework for the researcher. It allows readers to follow the researcher's activity and judge more clearly the value of the conclusions (Phillips \& Brown, 1993). The critical hermeneutic approach is between the radical humanist paradigm and the interpretive paradigm (Burrell \& Morgan, 1979). The method of hermeneutic research does not seek to develop theories or templates, Critical hermeneutics has high potential as well as serious challenges in the research areas of diversity and history, but critical hermeneutics is a relatively new methodology in organization and management studies (Yu et al., 2018). Critical hermeneutics focuses on two principles in the studies of organization and management: how particular texts influence the perception of people playing a role inside and outside the organization and how this perception influences the behaviour of these people (Danaiefard, Amrollahi Buyuki, \& Fatemi Aqda, 2016).

\section{Critical Hermeneutics as an Interpretive Method}

As Prasad (2005) notes, empirical research done from a critical hermeneutics tradition is premised upon four basic concepts: questions of author intentionality, layers of texts, hermeneutic circle, and relating to texts. These four precepts of the methodological approach make critical hermeneutics a helpful way for understanding the hidden meaning and purpose of texts (Peng, Yu, \& Mills, 2015). In this research, the steps of critical hermeneutic research method according to Prasad's (2005) model to clarify the concepts of leadership and directing in the texts of organization and management, have been taken as follows:

\section{Questions of Authors Intentionality}

In the critical hermeneutic analysis, there is no hypothesis and researchers pose the research questions based on their premises (Adib Haj Baqeri, Parvizi, \& Salsali, 2010). The philosophy of hermeneutics is concerned with the question of author intentionality in a text's creation (Prasad, 2005). The main question of this study is:

- What ambiguities does the application of the concepts of leadership and directing have in the theories of organizational leadership according to the critical hermeneutic approach?

Subsidiary or guiding questions were:

- How is directing applied in literature on leadership?

- How is leadership applied in literature on leadership?

- What are the similarities between directing and leadership?

What are the differences between directing and leadership?

2. Layers of texts

It starts with a choice of text(s) and related references as an interpretive starting point. Prasad (2005) suggests the notion of subtext or the text underneath the surface-text. The notion of layers of texts adds theoretical sophistication to critical hermeneutics as a more powerful tool to engage with 
complexity (Yu et al., 2018). In this research, we have reviewed the English texts related to the theory of organizational leadership and the definitions of the word directing in management texts and Persian texts by Iranian researchers who are concerned with the definitions of organizational leadership over several years and almost consecutive years, which are listed in Table 1 and 2. In this way, by studying the layers of texts and extracting the themes of related texts, the discrepancies and ambiguities in the definitions can be revealed as much as possible. In studying the historical course of definitions of organizational leadership in the layers of texts, what is most striking is that the confusion between the concept of leadership and directing has become more prevalent among researchers in recent years.

\section{Hermeneutic circle}

This step analysis fulfills the hermeneutic circle and provides a valuable interpretation for the particular relationship between text and context (Yu et al., 2018). The concept of the hermeneutic circle is one of an iterative spiral of understanding (Arnold \& Fischer, 1994), which asserts that the text can only be understood from the context, while the context can only be understood from the text (Prasad \& Mir, 2002). In this research, in order to better perform the hermeneutic cycle between the text and the concept, the themes from the texts related to the definitions of leadership and directing were extracted. Definitions and themes extracted from the text are given in Table 1 and 2. Then, the themes and concepts extracted from the text of organizational leadership are listed in Table 3; after that, a narrative case of the experience of one of the organizational leaders has been used to make the distinction between concepts of leadership and directing clearer. We moved to context illustration, followed by interpretations that manifest how to close the hermeneutic circle. By closing the hermeneutic cycle, the answers to the questions of the first step were obtained. In the following, a narrative case was mentioned with the subject of personal experience of one of the organizational leaders to understand the difference between the nature of leadership and directing tangibly.

\section{Narrative}

The best example of perceiving the difference between leadership and directing is the personal experience of Galen (2017), which was presented in a conference. According to his statements, Galen is the vice-president of software development in his company. In order to criticize a problematic procedure in the software regarding their greatest customer, he gathered the key members in a room, and they tried to solve the problem through brainstorming. Galen put the clock down and asked all the members to provide a solution for the problem no matter the passage of time. They remained in the room for about two hours. Finally, Galen intuitively perceived that there was no problem with his team. However, they all expected him to share his ideas and show leadership in order to solve the problem. They all waited for his next instruction, idea, or strategy as soon as there was a pause for even a second. The reality was that among all the skills, knowledge, and brains available in the room, Galen was the sole person who was seriously involved in the situation, and the rest waited for his next step. All of a sudden, he felt that he is the worst person within the room, thus as an efficient leader, it seemed to him that the best action is to leave the place so that he would allow the team to do what is required. He replaced himself with the operator of software testing. Therefore, the team concentrated, the problem was diagnosed, and it was solved step by step. Their attempts exceeded all expectations. Therefore, short-distance leadership is not always the best approach; sometimes, the best strategy is to direct from afar to provide the necessary 
atmosphere, support, and self-confidence. This is the difference between true directing and correct leadership (Galen, 2017).

4. Relating to texts

A necessary principle of hermeneutic tradition is the philosophical reflection concerned with the relationship between texts and their interpreters (Yu et al., 2018). In the fourth step, the researcher suggests a conceptual framework that provides a richer interpretation for the specific relationship between text and context (Prasad \& Mir, 2002). In this research, according to the features expressed in the theories for the concepts of leadership and directing, it has been suggested that experts consider the differences in applying these concepts. According to the critical hermeneutics findings of this study, the position of directing among different styles of organizational leadership is also determined and is shown in Figure 1.

\section{Findings}

According to the collected statements of experts on the definitions of organizational leadership and directing in specialized texts of organization and management, the research questions can be answered as follows:

- Main question: what ambiguities does the application of the concepts of leadership and directing have in the theories of organizational leadership?

- Findings: According to the collected definitions, 12 statements of theorists in Table 1 have defined leadership through directing and regarded them as equivalent, including Ladkin (2020); Sadaq (2019), Canton (2013), Kiliç and Günsel (2019), Denhart and Denhart (2006), Blanchard and Muchnick (2003), Ciulla (2005), Katz and Kahn (1978), Barnard (1997), Hosseini et al. (2014), Akbari et al. (2015), and Pourvali et al. (2017). However, if leadership is merely defined and interpreted through directing, the role of followers will be ignored in the leadership relationship. The confused discussion about leadership and directing in scientific texts of organization and management has continued to the extent that authors such as Jabbari, Darani, and Rahiminejad (2019) and Koontz and O'Donnell (1976) have not only regarded leadership and directing as equivalent but also considered both to be the duties of managers. However, a manager in any hierarchy is not obliged to play the role of a leader and have followers. Since the word "leader" makes sense through having follower(s), subordinates carrying out the instructions suffice for managers, according to the official order of the organization, and there is no need for followers' voluntary dedication (Blom \& Lundgren, 2020). Furthermore, since the clarity of managersubordinate relationship, which is according to an official employment contract and the hierarchical division of labor and does not require absolute obedience, is different from a leader-follower relationship (Alvesson et al., 2017; Uhl-Bien, Riggio, Lowe, \& Carsten, 2014), a leader is not always regarded as a manager, and their duties are not always the same.

- Question: how is directing applied in literature on leadership?

- Findings: according to the results of Table 2, most experts of management agree that directing is one of the duties of managers and a process of issuing an instruction to achieve the goals of the organization. However, based on the critical hermeneutic method, the critical and ambiguous point is that some experts such as Koontz and O'Donnell (1976) and Jabbari et al. (2019) believe that directing and leadership are synonym and consider both to be the duties of managers; while managers, unlike leaders, do not require followers in the process of directing as a duty. Some other experts like Dimock (1975) consider directing a factor in providing active leadership; on the 
contrary, experts such as Rudani (2013) considers leadership to be one of the significant tools of directing. Therefore, according to the mentioned findings, the texts of literature on leadership is not coherent enough regarding the use of the word "directing".

- Question: How is leadership applied in the literature on leadership?

- Findings: the concepts and themes extracted from different texts in order to define organizational leadership in the present study are as follows: the process of influence, process, directing, using power, the ability to influence. As shown in Table 1, some other concepts have also been used to define leadership; however, these five concepts have been repeated more frequently in texts. Other concepts applied in the definition of organizational leadership include creative problem-solving, all the structured acts of managers, powerful relationships, the mechanism of solving problems, the ability to encourage, skill, influencing relationship, and art. Among the mentioned concepts, the process of influence has the highest frequency of repetition in the experts' writings for the definition of leadership. Furthermore, directing is ranked second and the ability to influence and using power are ranked third and fourth.

Table 3

The Themes of the Definition of Organizational Leadership

\begin{tabular}{|c|c|}
\hline Themes & Resources \\
\hline $\begin{array}{l}\text { The process } \\
\text { of influence }\end{array}$ & $\begin{array}{l}\text { (Kochan et al., 1975), (Burns, 1978), (Kreitner \& Kinicki, 1992), (Zand, 1997), (Lussier \& Achua, 2001), (Northouse, 2010), } \\
\text { (Sugerman \& Scullard, 2011), (Alvesson \& Spicer, } 2012 \text { \& 2013), (Maxwell, 2013), (Algahtani, 2014), (Griffith et al., 2018), } \\
\text { (Antonakis \& Day, 2018), (Bratoon, 2020), (Saatchi, 1996), (Salimi \& Shahmandi, 2008), (Janmashayekh \& Barzideh, 2010), } \\
\text { (Rezaian, } 2003 \text { \& 2014), (Hakkak et al., 2016), (Mirzaei Daryani et al., 2019) }\end{array}$ \\
\hline Directing & $\begin{array}{l}\text { (Katz \& Kahn, 1978), (Barnard, 1997), (Blanchard \& Mucknick, 2003), (Ciulla, 2005), (Denhart \& Denhart, 2006), (Canton, } \\
\text { 2013), (Majed, 2019), (Kiliç \& Günsel, 2019), (Ladkin, 2020), (Hosseini et al., 2014), (Akbari et al., 2015), (Pourvali et al., } \\
\text { 2017) }\end{array}$ \\
\hline Process & $\begin{array}{l}\text { (Hersey \& Blanchard, 1969), (Yukl, 1989), (Gardner, 1990), (Drath \& Palus, 1994), (Humphrey, 2002), (Yammarino, 2013), } \\
\text { (Mousakhani \& Mohammadnia, 2006), (Afjei, 2006), (Farazja \& Khademi, 2011), (Afjei \& Hamzepour, 2014) }\end{array}$ \\
\hline $\begin{array}{l}\text { The ability to } \\
\text { influence }\end{array}$ & (Bennis \& Nanus, 1985), (Robbins, 1998), (Bogenschneider, 2016), (Alvesson \& Einola, 2019), (Torkzadeh \& Jafari, 2012) \\
\hline Using power & (Caroselli, 2000), (Klein et al., 2006), (Harris, 2009), (Collinson \& Tourish, 2015) \\
\hline
\end{tabular}

Considering the themes of Table 3, the definitions of organization leadership are not coherent enough. According to the critical hermeneutic method, the definitions of leadership, which are provided through the word "directing" are critically ambiguous and must be considered. Since these two processes have different natures and functions in the organization.

- Question: What are the similarities between directing and leadership?

- Findings: both directing and leadership have relational nature. Leadership is a process in which its result is reflected in directing and guiding the followers. A company can improve communications and social view, mission, policy, strategy, rules, and values of the company through coaching, guiding, and involving the employees in the formulation of policies (Kristiano, 2018). The essence of leadership is the relationship (Branson \& Marra, 2019). For example, when deciding to give the proper answer to shareholders and beneficiaries, leaders will allow their special type of relationships with beneficiaries to direct their communications (Fortunato, Gigliotti, \& Ruben, 2017).

- Question: What are the differences between directing and leadership?

- Findings: the scope of the word "leadership" lies entirely in human societies, the humanities, sociology, and similar fields. Despite the great diversity of the definitions of leadership, most experts agree on the dimensions of leadership process (i.e., leader, follower, influence) and the fact 
that leadership makes sense through a process of influence. However, the word "directing" which refers to finding the direction and guiding, can be applied to both humans and phenomena such as physics, chemistry, geography, agriculture, aviation, astronomy, and orchestra. In terms of nature, directing is not necessarily similar to leadership, which affects the leaded phenomenon. Directing may not even affect humans, i.e., directing may occur without influencing people and their perceptions or without any tangible and observable influencing, like a person who creates harmony and provides coordination between all the musicians of an orchestra. This person conducts the orchestra with no influence over people and without influencing them through his behavior and characteristics. Conducting the flow of electricity, heat, and water, guiding a mountaineering team, or guiding the multimillion-dollar missiles of NASA by monkeys in the space (Podsakoff, Niehoff, MacKenzie, \& Williams, 1993) are the examples of directing where influence is not necessarily required. When it is discussed about leadership, followers may help leaders to achieve not only the perspective, mission, and goals of the organization but also their personal goals and ambitions. However, directing focuses on a particular direction, i.e., it is aimed at organizing the disorder according to a formulated plan, so that the deviation from instructions and programs can be identified and removed. According to the definitions in Table 2, it can be argued that directing refers to employee guidance on what and when to do what is required in the framework of an organizational perspective. Director has no responsibility to people, while leadership involves people in the task and empowers them; the leader counts people and is responsible to them.

\section{Discussion}

Critical hermeneutics focuses on two principles in the studies of organization and management: how particular texts influence the perception of people playing a role inside and outside the organization and how this perception influences the behavior of these people (Danaiefard et al., 2016). Since it was impossible or often difficult to disentangle the 'leadership' activities from the other practices that enabled the leadership to take place, so the analysis needed to follow a hermeneutic reading (Sewchurran et al., 2020). According to the critical hermeneutic method applied in the present study, five questions were asked about the confusion of topics in the application of the concepts of directing and leadership in order to clarify ambiguities in the theory of organizational leadership. The results of this article are as follows:

After interpreting the definitions in Table 1, according to the extracted themes from the definitions of organizational leadership in Table 3, 12 resources have used the word "directing" and the concept of guidance in their interpretations such as Ladkin (2020), Majed (2019), Canton (2013), Kiliç and Günsel (2019), Denhart and Denhart (2006), Blanchard and Muchnick (2003), Ciulla (2005), Katz and Kahn (1978), Barnard (1997), Hosseini et al. (2014), Akbari et al. (2015), and Pourvali et al. (2017).These researchers insist that leadership is the correct directing and guidance on achieving particular goals; they do not differentiate between leadership and directing and have used these words interchangeably. However, other researchers have discussed the process of influence, developing and maintaining an influencing relationship with followers, and the ability to interact. However, if leadership is merely defined and interpreted through directing, the role of followers will be ignored in the leadership relationship. Bogenschneider (2016), in an article about the nature of leadership, has divided the main elements of the general theory of leadership into five components: leader (as the target person), followers (the target group including person(s) who are subject to obey the target person), the project which is merely accessible by the target group (human attempt), difficulties (real or false resistance to the project advancement), and the determining effect 
(which the project will worsen or fail miserably in the absence of this component). According to this general formula, leadership theories have been categorized into four causal propositions. Proposition 1: the relationship between leader and followers. Proposition 2: followers' commitment to the project. Proposition 3: difficulties with the project. Proposition 4: the determining effect, which reduces resistance and difficulties. The general theory of leadership states that leaders encourage followers to progress the project through the determining effect despite difficulties (Bogenschneider, 2016). Researchers such as Bogenschneider (2016), Branson and Marra (2019), Berg and Karlsen (2016), Galen (2017), and Mirzaei Daryani et al. (2019) believe that leadership is not just directing and they cannot be used interchangeably. Because according to them, followers are an important part of leadership theory. There is a difference between a leader-follower's relation and a formal hierarchical relation between the manager- subordinate. Subordinates often accept a manager's formal authority, power, and rights, but do not consider it necessary to comply with selfsacrifice or become devoted followers (Alvesson et al., 2017; Uhl-Bien et al., 2014). One of the main reasons for the difference between leadership and directing is the difference between those who are directed and those who follow their leadership. From an epistemological point of view, followership can be considered a voluntary reduction of influence. Therefore, since leadership includes an element of voluntary compliance (Blom \& Lundgren, 2020), just as authors have made directing a task for managers, leadership cannot be considered an official task for managers, as it would gainsay the authority of non-compliance because the formal duty is not voluntary. Nevertheless, some authors such as Koontz and O'Donnell (1976) and Jabbari et al. (2019) believe that directing and leadership are synonym and consider both to be the duties of managers; while managers, unlike leaders, do not require followers in the process of directing as a duty. Leadership cannot be regarded as a duty for managers.

Leadership is a term that is fully embedded in human societies and the humanities, and so on; and that leadership makes sense in the process of influence, while directing is a word that means determining direction and guidance that can be used for phenomena in addition to human beings. Even directing human use may not require any influence. That is, directing may occur without the need to influence and perceive people, or without tangible and visible impact.

Some researchers like Dimock (1975) regard directing as a factor in providing active leadership; on the contrary, another group of experts such as Rudani (2013) considers leadership to be one of the significant tools of directing. Therefore, according to the mentioned findings, the texts of literature on leadership is not coherent enough. The similarity between leadership and directing is that both of them have relational nature.

The word "directing" means guiding and moving ahead of other people to show the direction. Leaders do not stand aside, but rather encourage people and stand in the front to facilitate the progress (Kristiano et al., 2018). Burns (1978), whose statements are the most quoted definition of leadership, believes that leadership occurs when people are involved with others in a task. According to this definition, in Galen's (2017) experience narrated in this study, the difference between leadership and directing is obvious, i.e., the more people are involved in the task, the more it can be assured of leadership, otherwise directing occurs. However, it does not mean that one is preferable to the other and is more efficient; according to Galen's narrated experience, each must be used based on working conditions. Leaders generally need to communicate with their followers and engage in goals in order to facilitate meaning-making for those doing the work. Therefore, Leader's physical distance from their colleagues limited their ability to connect and engage, making 
leadership in the flow of practice more difficult (Sewchurran et al., 2020). Directing, according to the definitions in Table 2 in general, involves issuing instructions to subordinates and supervising them. There is no need for constant communication and engagement in work and physical presence.

Director has no responsibility to people, while leadership involves people in the task and empowers them; the leader counts people and is responsible to them. If different styles of leadership process are regarded as a spectrum in terms of the amount of interference and engagement in tasks and the amount of influence, it is understood that the greatest engagement in tasks and strongest influence on followers and non-delegation of authority at the top of the spectrum is associated with authoritarian leadership style; on the contrary, laissez-faire leadership style indicates the smallest engagement and intervention and most delegation of authority if leadership leads to authoritarianism (Cheng et al., 2004) because it engages directly in the leadership process, so directing is minimal. In the coaching leadership style (Hamlin et al., 2006; Ellinger et al., 2008; Pousa et al., 2018), which the leader trains the followers and makes them capable, so the directing is balance, and in the laissez-faire leadership style (Bass \& Avolio, 1994), which delegates authority to the followers, the directing is applied to the maximum extent.

Based on the findings of the present study, a range of leadership styles is shown in Figure 1 in terms of influence and directing aspect of leadership.

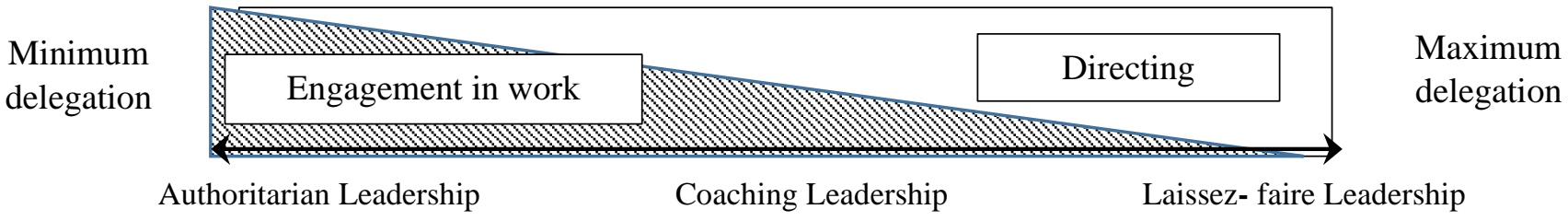

Figure 1. The spectrum of leadership styles to compare directing and leadership

In the general form, leadership includes different types of theories, models, and styles and managers must be familiar with them in order to show leadership, so that they can apply the best style according to the organization's needs. In reality, what leaders do for their followers leads to the act and tendency to direct and guide the followers. Therefore, leadership is not just directing. Leadership is a process in which its result is reflected in directing and guiding the followers. A company can improve communications and social view, mission, policy, strategy, rules, and values of the company through coaching, guiding, and involving the employees in the formulation of policies (Kristiano, 2018). Therefore, directing is just a part of leadership. On this account, even if a leader is successful in their relationships, followers may need to be less led. Milner, McCarthy, and Milner (2018) state that in a coaching style, successful leaders raise followers' awareness and enable them to think, so that employees have less need of being controlled and directed and tend to progress (Berg \& Karlsen, 2016). This fact occurs in the laissez-faire leadership style.

\section{Conclusion}

According to the critical hermeneutic method, there is an apparent contradiction in the authors' definitions of leadership. Leaders are directly engaged in achieving the organizational goals and do not stand aside, while directing and guiding refers to moving ahead of other people to show the direction. The scope of the word "leadership" lies entirely in human societies, the humanities, sociology, and similar fields. In contrast, the word "directing" can be applied to both humans and phenomena such as physics, chemistry, geography, and agriculture. Directing is not necessarily 
similar to leadership, which influences the person or the directed phenomenon. In mere directing and guiding, directed people or phenomena may not exhibit the characteristics of an influenced follower or even they cannot be regarded as followers, by any means. However, Drucker (1999) believes that a leader makes sense only if they have followers. Obedience is a significant component of leadership, and the nature of a leader makes sense through having a follower(s) and as a result of influence.

According to the whole points mentioned above, it seems more reasonable not to regard leadership and directing as equivalent in scientific texts of organization and management. Leadership is exclusively used for humans, and as a process of influencing and being influenced, it gathers follower(s) around the leader. Sometimes, due to the leader's coaching, followers may become empowered to the extent that they do not need leaders' directing and controlling anymore. Furthermore, unlike directing, leadership cannot be regarded as the main duty of managers, since all managers are not obliged or required to have a follower. On the other hand, the leader-follower relationship is not the same as the manager-subordinate relationship, and it cannot be generalized to all managers in all organizations. Sometimes, in marketing or finance, some industries or companies in industrial groups are called "industry leader" or "market leader," which seems wrong. It is recommended that "market pioneer" or "marketing director" be replaced with the word "leader" in such context, since other organizations may obey because they are obliged to rather than influenced.

\section{References}

Abolalaie, B. (2017). Leadership formula (2nd ed.). Tehran: Industrial Management Organization.

Abu-Tineh, A. M., Khasawneh, S. A., \& Al-Omari, A. A. (2008). Kouzes and Posner's transformational leadership model in practice: The case of Jordanian schools. Leadership \& Organization Development Journal, 29(8), 648-660.

Adib Haj Baqeri, M., Parvizi, S., \& Salsali, M. (2010). Qualitative methodologies. Tehran: Nashr va Tabligh-e-Bashari Publications.

Afjei, S. (2006). Philosophical introduction, leadership theories, and organizational behavior (5th ed.). Tehran: SAMT Publications.

Afjei, S., \& Hamzehpour, M. (2014). A comprehensive approach to quantum leadership theory and its applications in the organization. The Thought of Strategic Management, 8(2), 161-204.

Akbari, M., Kashani, S., \& Hooshmand Chaijani, M. (2015). An investigation into the effect of shared leadership on commitment and productivity of working groups. Quarterly Journal of Organizational Behavior Studies, 4(5), 95-122.

Algahtani, A. (2014). Are leadership and management different? A review. Journal of Management Policies and Practices, 2(3), 71-82.

Alvani, M. (2009). General management. Tehran: Ney Publication.

Alvesson, M., Blom, M., \& Sveningsson, S. (2017). Reflexive leadership. London: SAGE.

Alvesson, M., \& Einola, K. (2019). Warning for excessive positivity: Authentic leadership and other traps in leadership studies. The Leadership Quarterly, 30(4), 383-395.

Alvesson, M., \& Spicer, A. (2012). Critical leadership studies: The case for critical performativity. Human Relations, 65(3), 367-390.

Alvesson, M., \& Spicer, A. (2013). Critical perspectives on leadership: Oxford handbook of leadership and organizations. Oxford: Oxford University Press.

Alvesson, M., \& Sveningsson, S. (2003). Good visions, bad micro-management, and ugly ambiguity: Contradictions of (non)leadership in knowledge-intensive organization. Organization Studies, 24(6), 961-988.

Antonakis, J., \& Day, D. V. (2018). Leadership: Past, present, and future. In J. Antonakis \& D. V. Day (Eds.), The nature of leadership (p. $3-$ 26). Sage Publications, Inc.

Arnold, S. J., \& Fischer, E. (1994). Hermeneutics and consumer research. Journal of Consumer Research, 21(1), 55-70. 
Aybaghi Esfahani, S., Hasani, A., \& Ameri, Z. (2018). Synergistic leadership: a postmodernism approach to enhance the maturity of employees' capabilities and human resource sustainability. Organizational Culture Management, 16(4), 899-925.

Barnard, C. (1997). The nature of leadership. In K. Grint (Ed.), Leadership, classical, contemporary, and critical approaches. Oxford: Oxford University Press.

Bass, B.M. (1990). Bass \& Stogdill's handbook of leadership, 3rd edition. New York, NY: The Free Press.

Bass, B. M., \& Avolio, B. J. (1994). Transformational leadership development: Manual for the Multifactor Leadership Questionnaire. Palo Alto, CA: Consulting Psychologists Press.

Bennis, W., \& Nanus, B. (1985). Leaders: The strategies of taking charge. New York: Harper \& Row.

Berg, M. E., \& Karlsen, J. T. (2016). A study of coaching leadership style practice in projects. Management Research Review, 39(9), $1122-1142$. doi:10.1108/mrr-07-2015-0157.

Blanchard, K., \& Mucknick, M. (2003). The leadership pill: The missing ingredient in motivating people today. New York: Simon \& Schuster.

Blom, M, \& Alvesson, M. (2015). All-inclusive and all good: The hegemonic ambiguity of leadership. Scandinavian Journal of Management, $31(4), 480-492$

Blom, M., \& Lundgren, M. (2020). The (in)voluntary follower. Leadership, 16(2), 163-179. https://doi.org/10.1177/1742715019888078.

Bogenschneider, B. (2016). Leadership epistemology. Creighton Journal of Interdisciplinary Leadership, 2(2), $24-37$.

Branson, C. M., \& Marra, M. (2019). Leadership as a relational phenomenon: What this means in practice. Research in Educational Administration \& Leadership, 4(1), 81-108. doi:10.30828/real/2019.1.4

Bratton, J. (Ed.). (2020). Organizational leadership. SAGE Publications Limited.

Burns, J. M. (1978). Leadership. New York: Harper \& Row.

Burrell, G., \& Morgan, G. (1979). Sociological paradigms and organizational analysis: Elements of the sociology of corporate life. London: Pearson Education.

Cambridge Online Dictionary (2020). Retrieved form

http://dictionary.cambridge.org/dictionary/english/direct?q=directing.

Canton, L. G. (2013). Disaster planning and management: Does one leadership style work for both? Journal of Leadership Studies, 7(3), 47-50. doi:10.1002/j1s.21297.

Caroselli, M. (2000). Leadership skills for managers (1st ed.). New York: McGraw-Hill Education.

Chandra Bose, D. (2012). Principles of management and administration. Delhi: PHI Learning Private Ltd.

Cheng, B. S., Chou, L., Wu, T. Y., Huang, M., \& Farh, J. L. (2004). Paternalistic leadership and subordinate responses: Establishing a lead-ership model in Chinese organizations. Asian Journal of Social Psychology, 7,89-117. http://dx.doi.org/10.1111/j.1467-839X.2004.00137.x

Ciulla, J. B. (2005). Integrating leadership with ethics: Is good leadership contrary to human nature? In P. J. Doh \& S. A. Stumpf (Eds.), Handbook on responsible leadership and governance in global business (pp. 159-179). Cheltanham, Northampton: Edward Elgar.

Collinson, D. L., \& Tourish, D. (2015). Teaching leadership critically: New directions for leadership pedagogy. Academy of Management Learning and Education, 14(4), 576-594.

Dale, E. (1978). Management: Theory and practice. New York: McGraw-Hill.

Danaiefard, H., Amrollahi Buyuki, N., \& Fatemi Aqda, S. (2016). The association between critical hermeneutics and the studies of organization and management: An analysis of philosophical foundations and its execution manner in organizations. Quarterly Journal of Interdisciplinary Studies in Humanities, 8(2), 29-56.

Denhardt, R. B., \& Denhardt, J. V. (2006). The dance of leadership, the art of leading in business, government and society. London: Routledge.

Dimock, M. E. (1975). Administrative vitality. New York: Harper Brothers.

Drath, W. H., \& Palus, C. J. (1994). Making common sense: Leadership as meaning-making in a community of practice. Greensboro, North Carolina: Center for Creative Leadership.

Drucker, P. F. (1999). Knowledge worker productivity: The biggest challenge. California Management Review, 41(2), 79-94.

Ellinger, A. E., Ketchen, D. J., Jr., Hult, G. T. M., Elmada g, A. B., \& Richey, R. G., Jr. (2008). Market orientation, employee development practices, and performance in logistics service provider firms. Industrial Marketing Management, 37, 353-366. doi: 10.1016/j.indmarman.2007.01.002

Farazja, M., \& Khademi, M. (2011). The relationship between transformational and transactional leadership styles and the attitude towards organizational change. Innovations of Educational Management, 6(4), 50-69.

Fiedler, F. E., (1978). The contingency model and the dynamics of the leadership process. Advances in Experimental Social Psychology, 59-112. https://doi.org/10.1016/S0065-2601(08)60005-2 
Fontana, A., \& Musa, S. (2017). The impact of entrepreneurial leadership on innovation management and its measurement validation. International Journal of Innovation Science, 9(1), 2-19.

Fortunato, J. A., Gigliotti, R. A., \& Ruben, B. D. (2017). Racial incidents at the University of Missouri: The value of leadership communication and stakeholder relationships. International Journal of Business Communication, 54(2), 199-209. doi:10.1177/2329488416687056.

Galen, B. (2017). Stop leading from the front and the tutorials agile test team leadership: From concept to product, agile testing: Team tactics that deliver the goods, and test automation strategies for the agile world. Paper presented at the STAREAST Conference. Orlando, FL.

Gardner, J. W. (1990). On leadership. New York: Free Press.

Gini, A. L., \& Green, R. M. (2013). 10 virtues of outstanding leaders: Leadership and character. Hoboken, NJ: Wiley-Blackwell.

Griffith, J. A., Gibson, C., Medeiros, K., McDougall, A., Hardy, J., \& Mumford, M. D. (2018). Are you thinking what I'm thinking? The influence of leader style, distance, and leader-follower mental model congruence on creative performance. Journal of Leadership \& Organizational Studies, 25(2), 153-170.

Gulick, L. H. (1937). Notes on the theory of organization. In L. Gulick \& L. Urwick (Eds.), Papers on the science of administration (pp. 3-45). New York: Institute of Public Administration.

Hakkak, M., Shariatnejad, A., \& Saedi, A. (2016). Analyzing the effect of transformational leadership on innovative behavior and entrepreneurship development to achieve sustainable organizational competency. Quarterly Journal of Human Resource Studies, 6(22), 71-100.

Hamlin, R. G., Ellinger, A. D., and Beattie, R. S. (2006). Coaching at the heart of managerial effectiveness: a cross-cultural study of managerial behaviours. Human Resource Development International, 9, 305-331. doi: 10.1080/13678860600893524

Harris, A. (2009). Distributed leadership: Different perspectives. Dordrecht, Netherlands: Springer Science \& Business Media Press.

Hersey, P. \& Blanchard, H. K. (1969). Management of organizational behavior: Utilizing human resources. Englewood Cliffs, N.J.: PrenticeHall.

Hibbert, Paul, Nic Beech, \& Frank Siedlok (2017). Leadership formation: Interpreting experience. Academy of Management Learning \& Education, 16(4), 603-622.

Horner, M. (1997). Leadership theory: past, present and future. Team Performance Management: An International Journal, 3(4), $270-287$. doi:10.1108/13527599710195402

Hosseini, S., Mousavi, S., \& Khosravi Laghab, Z. (2014). Conceptual model of effective factors on leadership intention: Researched and studied among management students of public universities of Tehran. Researches of Human Resource Management, 3(4), 93-111.

Humphrey, R. H. (2002). The many faces of emotional leadership. The Leadership Quarterly, 13(5), 493-504. doi:10.1016/S1048-9843(02)001406.

Irani, H., Alvani, S., Jandaqi, G., \& Zarei Matin, H. (2015). Designing a generous leadership model of Iranian public hospitals in Qom Province. Quarterly Journal of Iran Management, 10(38), 1-33.

Jabbari, M., Darani, K., \& Rahiminejad, A. (2019). Explaining the leadership styles and relational skills of managers. Quarterly Journal of Management Studies (Improvement and Transformation), 28(94), 109-136.

Jacobs, A. H. M. (2014). Critical hermeneutics and higher education: a perspective on texts, meaning and institutional culture. South African Journal of Philosophy, 33(3), 297-310. http://dx.doi.org/10.1080/02580136.2014.948327

Janmashayekh, P., \& Barzideh, E. (2010). A survey on the effect of teacher leadership style on primary school students' creativity in Kazeroon. Innovations of Educational Management, 6(1), 143-158.

Katz, D., \& Kahn, R. L. (1978). The social psychology of organizations (2nd ed.). New York: John Wiley \& Sons.

Kiliç, M., \& Günsel, A. (2019). The dark side of the leadership: The effects of toxic leaders on employees. European Journal of Social Sciences, 2(2), 51-56. http://dx.doi.org/10.26417/ejss-2019.v2i2-64.

Klein, K. J., Ziegert, J. C., Knight, A. P., \& Xiao, Y. (2006). Dynamic delegation: Shared, hierarchical and de-individualized leadership in action teams. Administrative Science Quarterly, 51(4), 590-621.

Kochan, T. A., Schmidt, S. M., \& DeCotiis, T. A. (1975). Superior-subordinate relations: Leadership and headship. Human Relations, 28(3), 279294. doi:org/10.1177/001872677502800306.

Koontz, H., \& O’Donnell, C. (1976). Management: A systems and contingency analysis of managerial functions. New York: McGraw-Hill Book Company.

Kreitner, R., \& Kinicki, A. (1992). Organizational behavior (2nd ed.). Homewood, IL: Irwin.

Kristiano, P. B., Rivai, A., \& Suharto, E. S. (2018). The influence of leadership style and organizational climate on employee performance through organizational commitment on Perum Pegadaian Branch East Bekasi. International Journal of Business and Applied Social Science (IJBASS), 4(6), 34-51.

Ladkin, D. (2020). Rethinking leadership: A new look at old questions. Edward Elgar Publishing. 
Longman Dictionary of Contemporary English, (2020). Retrieved from

https://www.ldoceonline.com/dictionary/director.

Lussier, R. N., \& Achua, C. F. (2001). Leadership: Theory, application \& skill development. Cincinnati, Ohio: South Western College Publishing, Thomson Learning.

Mackenzie, R. A. (1969). The management process in 3-D. Brighton, Massachusetts: Harvard Business Review.

Majed, S. Z. (2019). The role of leadership soft skills in promoting the learning entrepreneurship. Journal of Process Management - New Technologies, International, 7(1), 31-48. doi:10.5937/jouproman7-20122.

Maxwell, J. C. (2013). The five levels of leadership: Proven steps to maximize your potential. New York: Center Street.

Merriam-Webster's Online Dictionary (2020). Retrieved from

https://www.merriam-webster.com/dictionary/directing.

Milner, J., McCarthy, G., \& Milner, T. (2018). Training for the coaching leader: How organizations can support managers. Journal of Management Development, 37(2), 188-200. doi:10.1108/jmd-04-2017-0135.

Mirzaei Daryani, S., Aslizadeh, A., \& Sattari Ardabili, F. (2019). Organization and leadership bubble. Tehran: Noor-e-Elm.

Mousakhani, M., \& Mohammadnia, A. (2006). Presenting and explaining the indices of selecting modern leadership model and how to integrate them in organizations. Management of Organizational Culture, 4(14), 163-201.

Northouse, P. G. (2010). Leadership: Theory and practice (5th ed.). California: Sage.

Peng, N., Yu, T., \& Mills, A. (2015). Feminist thinking in late seventh-century China. Equality, Diversity and Inclusion: An International Journal, 34(1), 67-83. doi:10.1108/edi-12-2012-0112

Phillips, N. \& Brown, J. L. (1993). Analyzing Communication in and around Organizations: A Critical Hermeneutic Approach. The Academy of Management Journal, 36(6), 1547-1576. http://www.jstor.org/stable/256821

Podsakoff, P. M., Niehoff, B. P., MacKenzie, S. B., \& Williams, M. L. (1993). Do substitutes for leadership really substitute for leadership? An empirical examination of Kerr and Jermier's situational leadership model. Organizational Behavior and Human Decision Processes, 54(1), 144. https://doi.org/10.1006/obhd.1993.1001.

Pourvali, B., Nouri, A., \& Hosseini, M. (2017). Leadership in organizations: Leadership techniques and theories with an applied approach. Tehran: Ketab-e-Mehraban Publications.

Pousa, C., Richards, D. A., \& Trépanier, C. (2018). Managerial coaching of frontline employees: the moderating role of gender. Human Resource Development Quarterly, 29, 219-241. doi: 10.1002/hrdq.21322

Prasad, A., \& Mir, R. (2002). Digging deep for meaning: A critical hermeneutic analysis of CEO letters to shareholders in the oil industry. Journal of Business Communication, 39(1), 92-116. doi:10.1177/002194360203900105

Prasad, P. (2005), Crafting qualitative research: Working in the post-postitivist traditions. M.E. Sharpe, Armonk, NY.

Reiter-Palmon, R., \& Illies, J. J. (2004). Leadership \& creativity: Understanding leadership from a creative problem-solving perspective. The Leadership Quarterly, 15(1), 55-77.

Rezaian, A. (2003). The basics of organizational behaviour management. Tehran: SAMT Publications.

Rezaian, A. (2014). The basics of organization and management. Tehran: SAMT Publications.

Ricoeur, P. (1978). Explanation and understanding: On some remarkable connections among the theory of text, theory of action, and theory of history. In C. E. Reagan \& D. Stewart (Eds.), The philosophy of Paul Ricoeur (pp.149-166). Boston: Beacon Press.

Rost, J. C. (1993). Leadership for the twenty-first century. Greenwood Publishing Group.

Robbins, S. (1998). Organizational behavior: Concepts, controversies, applications. Upper Saddle River, N.J: Prentice Hall International.

Rudani, R. B. (2013). Principles of management. New Delhi: Tata McGraw Hill Education Private Ltd.

Saatchi, M. (1996). Applied psychology for managers. Tehran: Virayesh Publications.

Salimi, Q., \& Shahmandi, E. (2008). Relationship of transformational and transactional leadership style with the application of the learning organization in high schools of Isfahan City. Quarterly Journal of Management and Planning in Educational Systems, 1(1), 21-34.

Sewchurran, k, \& Zaina 1, \& Mcdonogh, j. (2020), Exploring within the 'black-box' of leadership to make sense of the performative dynamics of conversation. Leadership, 16(2), 200-219.

Shinde, S. V. (2018). Functions of management. North Carolina, US: Lulu Publication.

Smircich, L., \& Morgan, G. (1982). Leadership: The management of meaning. Journal of Applied Behavioral Science, 18(3), $257-273$.

Sugerman, J., \& Scullard, M. (2011). The 8 dimensions of leadership: DiSC strategies for becoming a better leader. San Francisco: BerrettKoehler Publishers, Inc. 
Thompson, J. B. (1981). Critical hermeneutics: A study in the thought of Paul Ricoeur and Jurgen Habermas. Cambridge, England: Cambridge University Press.

Torkzadeh, J., \& Jafari, S. (2012). Classical and modern leadership approaches and theories: Towards the leadership worldview. Quarterly Journal of Development of Human Resource Management and Support, 25, 91-134.

Uhl-Bien, M., Riggio, R. E., Lowe, K. B., \& Carsten, M. K. (2014). Followership theory: A review and research agenda. The Leadership Quarterly, 25(1), 83-104.

Von Rueden, C., \& Van Vugt, M. (2015). Leadership in small-scale societies: Some implications for theory, research, and practice. The Leadership Quarterly, 26(6), 978-990. http://dx.doi.org/10.1016/j.leaqua.2015.10.004.

Weihrich, H., \& Koontz, H. (1993). Principles of management: An analysis of managerial functions (10th ed.). New York: McGraw-Hill.

Yammarino, F. (2013). Leadership past, present and future. Journal of Leadership and Organizational Studies, 20(2), 149-155.

Yu, T., Mills, A. J., \& Peng, N. (2018). A reflexive critique of a critical hermeneutics analysis of Wu Zetian. Qualitative Research in Organizations and Management: An International Journal, 13(3), 250-260. doi:10.1108/qrom-10-2016-1454

Yukl, G. A. (1989). Leadership in organizations. Englewood Cliffs, NJ: Prentice Hall.

Zand, D. E. (1997). The leadership triad: Knowledge, trust, and power. Oxford: Oxford University Press.

Zareie Matin, H. (2014). Management of advanced organizational behavior (2nd ed.). Tehran: Agah Publications. 